現代ロシアのインフレ過程ー物価統計研究の視点から

佐藤智秋 愛媛大学

筆者は, 1998 2000年度文部省科学研究費補助金（国際学術研究・基盤研究（B）） による「ロシアの地域間の資金偱環」研究（研究者代表：田畑伸一郎）に参加しこの プロジェクトの中で, 主として,ここ10年ほどのロシアにおける統計制度の改革を調查 してきた。

ソ連時代には，統計制度の不備が経済運営の妨げになっており，1980年代後半から統 計制度の改革が始まる。筆者の関心は, 現代ロシアにおける統計改革の中身にあり, 研 究の目的は, ロシアは統計改革にどのように取り組み, 統計は改革の中でどのように変 わったのか明らかにすることにある。その際，ロシアの統計制度の中から，統計の要で ある物価統計を取り上げ，その中でも，消費者物価統計に焦点を当てる。それは，一般 に, 同統計が,インフレ指標，各種インデクセーション、デフレータとして幅広く利用 され，国民生活に最も関連があり，物価統計の中で重要な位置を占めているからである。

今回の報告は，1999年1月に開かれた北海道大学スラブ研究センター冬季シンポジウ ムでの報告「地域における統計作成の奏状一物価統計と就業統計を中心として一」（共 同報告）に続く，2回目の途中報告になる。今回は，インフレの代替指標としてロシア の研究者グループ（ライスカヤ，セルギェンコ，フレンケル等）により試作される「集 計インフレ指数」，さらに，広大なロシアにおいて地域別物価水準を比較するための現 行公式指標について報告を行った。

ソ連末期には，「隠蔽インフレ」や「抑圧インフレ」といったソ連経済独自のインフ レを推計した「代替インフレ指標」が作成されたが，移行期のロシアでも，末払い債務 の増大等と関連し代替インフレ指標が提案される。提案者等の見解には，一方で，先進 国の経済運営や統計制度に対する過大評価, 他方で, 自国の経済状況や統計制度, 各種 価格指標の有効性への過度の悲観がみられ，それが，代替指標の提案へとつながってい る。彼等の研究は，CPI が捕捉していない領域での物価変動について，独自の指摘を 積極的に行っている点, また, 自己相関関数・時差相関倸数などを使ったユニークな指 標の推計方法など, 様々なインフレ指標の研究の中での一つ試みとみるならば興味深い。 また，彼等の代替指標を検討することは、これまで先進国でなされている手法とは異な る角度から，ロシアの現行 C P I の有効性を吟味することにもなる。とはいえ，統計の 整備と代替指標の研究は別物と考えねばならない。この指標自体は, 消費者物価指数や その他物価指標の代替物にはならないからである。さらに実際にも, 既存の各種価格統 計の利用から得られる以上のものを，新たに「集計インフレ指数」を利用することから 
かつて「価格表」から計算された物価指数は, 社会主義体制下の物価変動を捕捉でき ず，マクロ経済指標を歪めることになった。そのため，特に物価統計の建て直しとその 信頼性の回復が急務となっており，ロシアは世界標準の採用によりここれを実現しよう とした。そして，公表される資料から判断する限りでは，かつての価格表から計算され た物価指数が持つような致命的な問題は克服されたとみなすことができる。

しかしながら，現時点では，新しい制度や方式の導入が，そのまま統計の有効性の向 上につながっていったと判断するのは難しい。ロシアの物価統計が抱える問題の多くは， どの国においても，程度の差こそあれ，物価統計を作成する際に生じている問題である が，経済が移行期にあること，市場経済での物価統計作成の释験の浅さ，広大な領土の ため市場が多様なこと等の理由により，統計に関わる問題が極端な形で発生しており， このような状況下で統計の有効性も制約されざるをなくなっている。債務の未払い, バーター，ドルでの取引など、ルーブルが排除された取引が広範に行われ，一国の価格 体系を複雑化している状況などは, まさに移行期ロシアの特殊な状況であり, 統計の改 善を困難なものにしている。

こうした中, 代替指標やユニークな手法が登場するのであるが，その場合も，統計の 改革を忽っていては, 満足のいく結果は得られない。ロシアにおいては, 今後も地道に 統計の整備を続けていく必要がある。

以上 


\title{
Inflation Process in Modern Russia - from the Viewpoint of Price Statistics Research
}

\author{
Tomoaki SATO \\ Ehime University
}

It is hard to judge that introduction of a new statistical system led to improvement in availability of statistics in Russia today. Though many of problems which Russian price statistics has take place in every country, they occur in the extreme form, because Russia is in a transition process, lacks for experience of producing the price statistics in the market economy and has a vast territory, etc. "Arrears", barter and transactions in dollars, in which ruble is eliminated, are widespread and it has complicated the price system of a country. Such a situation is just a special situation of Russia, and makes the statistical improvement difficult. 